\title{
NEOFANTÁSTICO EM "CAIU UMA ESTRELA NA MINHA SALA", DE MARCELO MOUTINHO
}

\section{NEO-FANTASTIC IN "CAIU UMA ESTRELA NA MINHA SALA", BY MARCELO MOUTINHO}

\author{
Jhennefer Alves Macêdo' \\ Valnikson Viana de Oliveira² \\ Luciane Alves Santos ${ }^{3}$
}

\begin{abstract}
Resumo: Um texto literário náo é imutável, pois a escrita de uma obra se adequa ao tempo, no qual é escrita, e ao leitor, para quem se destina. As crenças, as dúvidas, as inquietaçōes do receptor do texto literário se modificam e exigem, assim, uma adequaçăo para os novos horizontes de expectativa. Inserido nesse contexto de constantes modificaçōes, o gênero fantástico passou por diversas transformaçōes desde sua origem. O fantástico que, nos séculos XVIII e XIX, desestabilizou o mundo concreto e, aparentemente, organizado, hoje adquire novas feiçóes e causa desconforto e perplexidade, visto que grande parte da sociedade contemporânea já compreendeu que as leis que regem o universo nâo săo totalmente explicáveis. Nesse sentido, surge, na contemporaneidade, a denominada narrativa neofantástica, que se alinha à interiorizaçáo do medo, dos receios e dos temores típicos da modernidade. Com base nessas observaçôes, o presente trabalho objetiva expor um breve panorama das principais diferenças que o neofantástico apresenta frente ao fantástico tradicional, assim como analisar como esses novos elementos estăo presentes no conto "Caiu uma estrela na minha sala", do escritor carioca Marcelo Moutinho. Para fins de análise e discussāo, recorreremos aos apontamentos teóricos de Jaime Alazraki (1983; 2001), Tzvetan Todorov (2004) e David Roas (2014).
\end{abstract}

Palavras-chave: Neofantástico. Literatura brasileira contemporânea. Marcelo Moutinho.

1 Graduada em Letras pela Universidade Federal da Paraíba (UFPB) e mestranda no Programa de Pós Graduaçâo em Letras (PPGL) da mesma instituiçăo. E-mail: jhenneferufpb@outlook.com.

2 Graduado em Letras e Mestre em Letras pela Universidade Federal da Paraíba (UFPB). E-mail: valnikson18@hotmail.com.

3 Doutora em Letras pela Universidade de Săo Paulo. Líder do grupo de pesquisas “Variaçôes do insólito: do mito clássico à modernidade". Professora efetiva na Universidade Federal da Paraíba, vinculada ao programa Pós-graduaçăo em Letras (PPGL).E-mail: luciane.ufpb@gmail.com. 
Abstract: A literary text is not immutable, because the writing of a text is adapted to the period of time in which it is written, and the reader, to whom it is destined. The beliefs, doubts, anxieties of the receptor of a literary text change and, thus, require an adequacy to new horizons of expectations. Inserted in this context of constant modifications, the fantastic genre has undergone several transformations since its origins. The fantastic that, in the $18^{\text {th }}$ and $19^{\text {th }}$ centuries, destabilized the concrete and, apparently, organized world, nowadays acquires new features and cause discomfort and perplexity, since large part of the contemporary society has already understood that the laws that rule the universe are not entirely explicable. In this sense, in contemporainity, emerges a narrative called neo-fantastic, which is aligned with the internalization of fear, of the concerns and the typical worries of modernity. Based on these observation, the present paper aims to present a brief overview of the main characteristics of the neofantastic shows in relation to the traditional fantastic, as well as to analyse how these new elements are present in the tale "Caiu uma estrela na minha sala", by the carioca writer Marcelo Moutinho. For the purpose of analysis and discussion, we based on the theoretical appointments of Jaime Alazraki (1983; 2001), TzvetanTodorov (2004) and David Roas (2014).

Keywords: Neo-fantastic. Brazilian literature. Marcelo Moutinho.

\section{INTRODUÇÃO}

Na transiçăo entre os séculos XVIII e XIX, a sociedade esteve inserida em um contexto de busca por verdades absolutas, explicaçôes óbvias, resultados visíveis e palpáveis. Tudo que năo correspondesse a esses anseios era descartado. A religiăo, a fé, a magia, entre tantos outros instrumentos que, anteriormente, promoviam o entendimento através do crer e nâo do ver, perderam espaço para uma ciência que buscava assegurar o êxito de que todos os acontecimentos do nosso mundo eram ou deveriam ser explicáveis. Tornando-se ainda mais racionais, os homens internalizaram a teoria de que o nosso universo era regido por leis imutáveis.

Porém, com essa perspectiva, todas as incertezas, anseios, ilusôes, delírios e loucuras teriam sido abolidos da natureza humana? Com a teoria da verdade absoluta, o medo teria sido erradicado e para sempre escondido na clareza absolutista do Século das Luzes? Abraçando essas inquietaçôes da mente humana, o fantástico surge para romper com os limites da racionalidade e apontar para a desestabilizaçăo do mundo real. Segundo os estudos do crítico espanhol David Roas (2014), em meados do século XVIII, quando despontou na literatura, o gênero fantástico representaria uma espécie de contraponto ao racionalismo iluminista: o culto à razăo minimizou a fé no sobrenatural e o torna inofensivo, algo com que se pode brincar artisticamente.

A literatura fantástica, em seus primórdios, caminhou exatamente no inverso das coisas explicáveis: aquilo que náo poderia ser esclarecido pela ciência, constituía sua principal fonte de interesse. Objetivando quebrar o conjunto de regras assentado e desestabilizar a "normalidade" que pairava naquele século, o homem, através do texto fantástico, foi posto diante do seu maior temor: aquilo que ele năo pode governar ou explicar: "A literatura fantástica em geral investiga o náo dito e o náo visto da 
cultura: aquilo que tem sido silenciado, tornando invisível, ocultado e tornando ausente" (JACKSON apud BORDINI, 1987, p. 21).

Os textos fantásticos apresentavam personagens e situaçôes que, até entăo, de acordo com as leis científicas, nâo poderiam existir, pois "ora, o fantástico náo quer o impossível só porque ele é terrificante, quer porque ele é impossível. Querer o fantástico é querer o absurdo e o contraditório" (TODOROV, 2004, p. 42).

Despertando em seus leitores os seus medos mais íntimos, o gênero fantástico criou um mundo fictício semelhante ao real, permitindo assim que seu leitor se reconhecesse. Todavia, esse reconhecimento se tornava nulo no instante em que os elementos sobrenaturais apareciam e revelavam que o homem era governado por forças que ele nâo poderia administrar.

Muito embora tenhamos crescido ouvindo histórias de fadas, bruxas, dragóes, ogros e que esses seres, por vezes horripilantes, nos causassem aversăo, é pouco provável que em algum momento tenhamos interrompido a história para questionarmos a real possibilidade de existência desses personagens dos contos maravilhosos. É consenso entre a crítica especializada que o texto maravilhoso nos transporta para outro mundo, um espaço repleto de fantasias, em que todas as personagens e situaçóes, por mais estranhas que sejam, podem existir. O mesmo náo acontece quando nosso cotidiano é invadido por histórias de vampiros sanguinários e espectros que insistem na permanência em nosso mundo, no qual eles năo deveriam mais pertencer. Se esses já parecem ser personagens inquietantes, imaginemos, entâo, uma estátua que se move sozinha, um indivíduo que vomita coelhinhos (e nâo se questiona sobre isso) ou uma pata de macaco com poderes mágicos. Esses personagens e situaçōes despertam a perplexidade, pois desestabilizam o nosso referencial de normalidade.

Mas sabemos que a sociedade e o tempo estâo em constantes transformaçôes e cabe à literatura se refazer e adaptar-se aos novos anseios do seu público alvo. Se um dos objetivos da literatura fantástica era revelar as principais fragilidades inerentes ao ser humano, é perceptível que essas fragilidades e anseios também se modificam.

Embora o medo, importante característica do gênero fantástico tradicional, jamais tenha deixado de existir, os elementos que o causam se alteraram, exigindo, assim, que a proposta do texto fantástico também se remodele, adquirindo uma nova roupagem. Surge entăo uma nova literatura, a qual irrompe o real náo apenas para mostrar o sobrenatural, mas para questionar, para apresentar a anormalidade da realidade.

É observando esse novo panorama da literatura fantástica que objetivamos desenvolver uma análise no conto "Caiu uma estrela na minha sala", de Marcelo Moutinho. Apontaremos alguns aspectos da quebra de normalidade nos elementos que constituem essa narrativa, elencando as características que o definem como uma obra neofantástica e que, de certa forma, o distanciam do texto fantástico tradicional.

\section{DO FANTÁSTICO AO NEOFANTÁSTICO}

Os estudos sobre a literatura fantástica despertaram em muitos pesquisadores o interesse por descortinar esse gênero, objetivando pontuar os atributos que o constitui como tal. Contudo, inserir essa literatura em um único modelo seria cair em inevitável 
reducionismo. Em relaçăo à constituiçăo do gênero literário, devemos a primazia da análise ao teórico franco-búlgaro Tzvetan Todorov, em sua célebre obra Introduçâo à literatura fantástica (2004). De acordo com o autor, "năo nos arrisquemos a definir o fantástico: os próprios editores da Cheeklist of fantastic literature a tal renunciaram. Quanto às definiçôes dos dicionários, puxa cada uma para o seu lado" (2004, p. 7).

Se a definiçăo parece arriscada, Todorov conceitua o fantástico como "a hesitaçáo experimentada por um ser que só conhece as leis naturais, face a um acontecimento aparentemente sobrenatural" (TODOROV, 2004, p. 31). Para ele, a ambiguidade deve se "manter até o fim da aventura: realidade ou sonho? Verdade ou ilusâo?" (TODOROV, 2004, p. 30). Esses questionamentos levam o leitor para a profundeza do fantástico, conforme observa:

[...] num mundo que é exatamente o nosso, aquele que conhecemos, sem diabos, sílfides, nem vampiros, produz-se um acontecimento que năo pode ser explicado pelas leis deste mesmo mundo familiar. Aquele que o percebe deve optar por uma das soluçóes possíveis; ou se trata de uma ilusăo dos sentidos, de um produto da imaginaçáo e nesse caso as leis do mundo continuariam a ser o que săo; ou entăo o acontecimento realmente ocorreu, é parte integrante da realidade, mas neste caso a realidade é regida por leis desconhecidas para nós (TODOROV, 2004, p. 30).

Regatando estudos anteriores e ampliando a discussáo em torno do gênero, Todorov classifica os temas do fantástico em temas do eu (ou do olhar) e temas do tu (ou do discurso). Os primeiros referem-se ao "isolamento do homem em sua relaçăo com o mundo que constrói, enfatizando esse confronto sem que um intermediário tenha que ser nomeado" (TODOROV, 2004, p. 164). Já os segundos tratam da sexualidade, da relaçấo do homem com seu desejo, com forte açăo sobre o mundo circundante, descrevendo o "desejo sexual [...] particularmente suas formas excessivas bem como suas diferentes transformaçóes, ou se quisermos, perversōes" (TODOROV, 2004, p. 147).

Ainda de acordo com o referido estudioso, o elemento sobrenatural do fantástico está presente na sociedade desde os tempos mais remotos, fazendo parte do incontável acervo de lendas que transita entre geraçōes. Em consonância a esse pensamento, Bordini (1987, p. 11) também ressalta que "Certos elementos tidos por aterrorizantes, como seres que se alimentam de sangue, espectros que assombram os vivos, homens que se metamorfoseiam em feras povoam o imaginário popular desde há milênios".

Apropriando-se desses personagens sobrenaturais, o fantástico tradicional teve como objetivo inserir os temores sobrenaturais no mundo real. Em outras épocas, as histórias de lobisomem, vampiros, fantasmas, monstros, inspiravam tamanho medo que, por vezes, cogitou-se a verdadeira existência dessa galeria de seres: "Quer uma dessas certezas apareça contrariada por um facto - real ou ilusório - e o arreio do sobrenatural pode nascer" (TODOROV, 2004, p. 42).

Na concepçăo de Todorov (2004), é aí que se constitui a principal ruptura entre a percepçăo do leitor da literatura fantástica tradicional, cultivada no século XIX, e a do leitor do neofantástico, ${ }^{4}$ gênero difundido a partir do século XX. O primeiro

4 O termo "neofantástico" năo foi utilizado por Todorov e, sim, por Alazraki (2001, p. 280): "Propus la denominación neofantástico como um llamado de atención de las diferencias que he sinalado entre esos dos tipos de narración". Todorov (2004, p. 91) apresenta uma possível distinçăo entre o corpus narrativo do século 
estabelecia um pacto com o texto e a história: por mais ficcional que fosse, ganhava um tom realista. O segundo, imerso em conceitos da complexidade contemporânea, leria com descrédito as narrativas sobrenaturais. Os estudos de Jaime Alazraki apontam para um "rasgo distintivo" entre essas modalidades fantásticas:

Cómo definir algunas narraciones de Kafka, Borges o Cortázar, de indiscutible relieve fantástico pero que prescinden de los genios del cuento maravilloso, del horror del relato fantástico o de la tecnología de la ciencia ficción? Por supuesto que no se trata de una mera taxonomía. Se trata de una comprensión más a fondo de sus propósitos y alcances; se trata de fijar una visión que justifique su funcionamiento; se trata, en resumen, de establecer una poética de este tipo de relato que nos impresiona como fantástico (ya que no hay hombres que se conviertan en insectos o axolotls o que sean inmortales), pero que difiere radicalmente del cuento fantástico tal como lo con- cibe y practica el siglo XIX. (ALAZRAKI, 2001, p. 272).

A narrativa ficcional neofantástica se apresenta como uma máscara, como um tampo que oculta uma segunda realidade cujo objetivo năo é provocar o medo ou o temor, mas a perplexidade, a inquietude pelo insólito das situaçôes narradas. Essas narrativas săo, em grande parte, metáforas que buscam expressar as lacunas que escapam às explicaçôes racionais (ALAZRAKI, 2001, p. 277).

Em consonância com essa "nova" visăo do insólito, Roas (2014) compreende que o fantástico dependerá do conhecido, pois o leitor precisa contrastar o fenômeno sobrenatural com a concepçâo de realidade. Questionando os apontamentos todorovianos, o autor apresenta o seguinte esclarecimento:

Embora seja verdade que a filosofia moderna justifique perfeitamente essa ideia, nossa experiência da realidade continua nos dizendo que os seres humanos năo se transformam em insetos nem vomitam coelhos vivos (como o protagonista de "Carta a uma senhora de Paris", de Cortázar). Assim, possuímos uma concepçăo do real que, ainda que possa ser falsa, é compartilhada por todos os indivíduos e nos permite, em última instância, recuperar a dicotomia normal/anormal em que se baseia toda narrativa fantástica. (ROAS, 2014, p.77).

Mesmo que năo sejamos mais regidos por verdades absolutas ou por teorias científicas em que tudo se explica, permanecemos acreditando que a realidade segue certa coerência e que leis imutáveis nos governam. Segundo Roas (2014), o que caracteriza o fantástico contemporâneo é a irrupçăo do anormal em um mundo aparentemente normal. Sendo assim, ao ver a realidade transgredida, o leitor descobrirá que o mundo náo funciona exatamente como pensamos. Dessa forma, o fantástico dependerá sempre do que seja considerado real.

\section{MARCELO MOUTINHO E O CONTO FANTÁSTICO}

O argentino Julio Cortázar foi autor de diversos ensaios com alguns princípios considerados como regentes do gênero conto e da inserçâo do fantástico na produçâo literária contemporânea, em uma rica produçăo crítica advinda de sua vivência

XIX e aquele que advém após a obra de Franz Kafka (1883-1924): "[...] a diferença entre o conto fantástico clássico e os relatos de Kafka: o que no primeiro mundo era uma exceçăo se converte aqui na regra". 
enquanto escritor e pesquisador. Nessa perspectiva, Cortázar compara a realizaçâo contista à arte de fotografar, trazendo a ideia de que um texto do gênero deve apontar sentidos para além de suas próprias fronteiras, escolhendo e limitando uma imagem ou acontecimento que seja significativo, capaz de "atuar no espectador ou no leitor como uma espécie de abertura, de fermento que projete a inteligência e a sensibilidade em direçâo a algo que vai muito além do argumento visual ou literário" (CORTÁZAR, 2006, p. 151-153).

Para melhor exemplificar seus apontamentos, ele também estabelece uma comparaçâo entre o conto e o romance, apontando que, enquanto o primeiro gênero corresponderia a uma arte sintética, trabalhando com a seleçâo de elementos significativos, o segundo se relacionaria a uma arte mais analítica, trabalhando com a acumulaçáo de material. Cortázar chega a postular que o conto é um "resumo implacável de certa condiçâo humana" ou mesmo um "símbolo candente de uma ordem social ou histórica" (2006, p. 153). A partir disso, também traça um paralelo entre a gênese de um conto e a de um poema, apontando para a açăo de exceder o que seria "normal" através da escrita.

[...] se o ato poético me parece uma espécie de magia de segundo grau, tentativa de posse ontológica e náo já física como na magia propriamente dita, o conto năo tem intençôes essenciais. A gênese do conto e do poema é, contudo, a mesma, nasce de um repentino estranhamento, de um deslocar-se que altera o regime 'normal' da consciência [...] (CORTÁZAR, 2006, p. 234, grifo nosso).

Corroborando essa ideia, Alfredo Bosi (1975, p. 31) indica que o conto funcionaria como uma espécie de "poliedro capaz de refletir as situaçóes mais diversas de nossa vida real ou imaginária" e que, devido às variadas possibilidades temáticas e da pequena extensăo que geralmente possui, apresentaria uma maior circulaçăo, compreendendo consequentemente um público leitor mais amplo e diversificado.

O conto fantástico, para Cortázar (2006), seria aquele que contém um elemento estranho rompendo com o que é natural ou habitual. Ademais, esse autor indica que seria necessário que o fator excepcional passasse a "ser também regra sem deslocar as estruturas ordinárias entre as quais se inseriu" (CORTÁZAR, 2006, p. 235). Sendo assim, entende-se que o componente fantástico deveria logo se integrar à ordem comum do cotidiano narrado.

Ainda segundo o referido teórico, o elemento fantástico năo deveria aparecer o tempo todo (full-time) no conto, nem ser do tipo deus ex-machina, surgindo ao seu desfecho para solucionar algum impasse (CORTÁZAR, 2006, p. 236); ele năo se desassociaria da realidade dentro do texto, estabelecendo um pacto de verossimilhança com o leitor. As grandes surpresas nos esperariam ali "onde tivermos aprendido por fim a năo nos surpreender com nada, entendendo por isto năo nos escandalizarmos diante das rupturas da ordem" (CORTÁZAR, 2006, p. 179). A proposta aqui seria desenvolver a história despertando ainda mais a imaginação do leitor, oferecendo-lhe novas sensaçóes que em nada o excluem da experiência do real.

Voltemo-nos agora para o escritor carioca Marcelo Moutinho. Além da produçáo literária, ele também já foi colaborador em diversos suplementos culturais do país e curador de importantes eventos em prol da leitura. Autor principalmente dedicado às formas literárias breves traz como marca de sua produçăo o enfoque no cenário urbano, sempre explorado de maneira náo convencional. Ao tirar potência e beleza do 
cotidiano comum, ele assume uma visăo contemporânea do gênero conto, năo dependendo necessariamente de uma trama permeada por um fio de tensăo, a ser explanado em um final desconcertante. Suas narrativas na verdade muito têm em comum com o gênero crônica, oferecendo um olhar agudo ao que é aparentemente trivial.

O autor parece sempre ultrapassar a inusitada descriçăo de flagrantes da cidade grande ao propiciar densidade emocional e certa profundidade a alguns personagens, ainda que suas tramas sejam bem definidas em concisăo. 0 exercício ficcional resulta em leveza de enredo e simplicidade de linguagem, sem excluir o requinte estrutural, já que o sofisticado nâo carece de formalismo ou afetaçâo. Em seus trabalhos, a sobriedade no jogo com as expectativas também se faz memorável ao leitor, que vai construindo aos poucos os sentidos guardados nas entrelinhas do texto. Ele utiliza a sobriedade como técnica para fomentar a conjectura diante do que é apenas sugerido.

A incidência do fantástico na obra de Moutinho existe desde a sua estreia nas letras, com a coletânea Memória dos barcos (2001), publicada em tiragem limitada pela editora independente 7 Letras. Esse livro já apresentava um estilo simples e lírico de tratar o imagético, envolvendo-o em subjetividade. Na sua mais recente publicaçăo, Ferrugem (2017), o autor retrata figuras ordinárias em conflito com a passagem do tempo, em sua maioria no cenário da cidade do Rio de Janeiro, unindo humor, encantamento e melancolia. Dos treze contos que fazem parte do compêndio, recebe destaque "Caiu uma estrela na minha sala", um dos únicos a apresentar deslizamentos pelo fantástico, mostrando que o extraordinário, embora quase sempre năo seja percebido, pode ter lugar na vida cotidiana. Trata-se de uma versăo revisada da narrativa que fecha o referido primeiro livro lançado pelo escritor.

O conto é prenunciado em uma das epígrafes do livro, um verso do poeta chileno Vicente Huidobro (1893-1948): En todos los caminos se ha perdido una estrella". Com título autoexplicativo, ele é narrado por um narrador personagem náo nomeado que presencia um episódio fantástico em sua casa, durante um domingo aparentemente banal. Uma estrela de cinco pontas cai no meio de sua sala e o desconcerta à primeira vista. No final, aquele corpo celeste acaba sendo acolhido por ele. O texto vai se revelando um claro exemplo da literatura neofantástica, fazendo com que embarquemos na "realidade irreal" do protagonista. No fundo, assim como várias outras figuras apresentadas por Moutinho, ele vive sob o espectro de estrelas que se perderam no caminho.

\section{ASPECTOS DO NEOFANTÁSTICO EM “CAIU UMA ESTRELA NA MINHA SALA”}

Como vimos anteriormente, o fantástico contemporâneo, assim como a vertente tradicional, visa produzir a incerteza diante do real, diferenciando-se dela por meio das novas formas de expressar a transgressăo. Retomando os apontamentos teóricos de Roas (2014), a literatura fantástica contemporânea está inserida na visâo pós-moderna da realidade, segundo a qual o mundo é uma entidade indecifrável, incerta, em que năo há verdades gerais.

As novas ideias acerca do real vigentes no século XX trazem a introduçăo de uma perspectiva mais ampla para a literatura. Nesse sentido, Alazraki (1983) conceitua como neofantástico o texto que imprime a condiçấo de obra aberta postulada pelo 
escritor e bibliófilo Umberto Eco (1932-2016), isto é, aquele que trabalha a linguagem de forma que o leitor tenha diferentes possibilidades de interpretaçáo, que rejeita regras ou normas que configuram uma maneira unívoca e definitiva de representaçâo da realidade. Tanto no fantástico como no neofantástico, há a ausência de causalidade. No segundo, porém, essa ausência é mais acentuada, pois nem leitor, nem personagens hesitam diante do episódio narrado. Há também o predomínio da ambiguidade, tornando a obra passível de uma contínua revisâo de valores e certezas devido à possibilidade permanente da mensagem significar o seu oposto.

No conto "Caiu uma estrela na minha sala", Marcelo Moutinho faz uso da narraçâo em primeira pessoa, um dos procedimentos narrativos e retóricos mais utilizados pelo modo fantástico, de acordo com Ceserani (2006). O narrador, năo nomeado, inicia o relato descrevendo o cenário de seu sobrado, onde se encontrava em mais um domingo comum e apático: estava sentado em uma cadeira de balanço, lendo o jornal acumulado da semana enquanto a TV estava ligada sem que ninguém assistisse à sua programaçăo. Para Alazraki, a narrativa neofantástica assume a "solidez" do mundo real para melhor devastá-lo (2001, p. 276), e é assim que o discurso revela um estado de profunda inércia e tranquilidade: "Eu movia lentamente a cadeira de balanço de modo a embalar a indolência" (MOUTINHO, 2017, p. 60).

Todavia, destoa na descriçăo a figura de uma abelha, que insiste em voar perto do enunciador: "A abelha zoava em seu voo ziguezagueante sem demonstrar nervosismo" (MOUTINHO, 2017, p. 59). O inseto parecia disputar com a TV a atençăo do personagem que, em seu discurso, afirma năo ter tido êxito ante a quietude daquele momento de leitura. No entanto, percebemos que ele năo consegue ater-se ao jornal, notando os detalhes ao seu redor. Aspectos textuais tendem a mostrar que a abelha nâo estava ali à toa, visto que havia algo "daquele clima de início de noite dos domingos, a preguiçosa espera que toca o crepúsculo e faz às vezes a morte se assanhar" (MOUTINHO, 2017, p. 59). Esse elemento voador pode ser interpretado de inúmeras formas, já que sua presença na narrativa năo tem explicaçăo clara e objetiva.

De acordo com Chevalier e Gheerbrant (1999, p. 3), as abelhas encontram-se "representadas nos túmulos como sinais de sobrevivência além-morte, pois a abelha torna-se símbolo de ressurreiçáo". Além da relaçaáo com a finitude e a imortalidade, elas, "[...] quando consideradas individualmente, na qualidade de animadoras do universo entre a terra e o céu, podem também simbolizar seu princípio vital, materializar a alma" (CHEVALIER; GHEERBRANT, 1999, p. 3).

A morte também é curiosamente o tema das falas do apresentador do programa Fantástico (escolha bastante sugestiva em relaçăo ao gênero com que a narrativa flerta) no instante em que o narrador passa a reparar no que a TV transmitia: "Em tom sisudo, o show da vida mostrava a morte num morro carioca. Autoridades por detrás de microfones, a música dolente, o plano que se fecha no rosto segundos antes de uma lágrima escorrer. Pausa para os comerciais" (MOUTINHO, 2017, p. 60).

O narrador nota que a abelha ziguezagueava cada vez mais veloz e para todas as direçóes enquanto o locutor falava, parecendo pressentir "que o tempo mudaria - e rapidamente" (MOUTINHO, 2017, p. 60). Apesar da insistência do inseto, o personagem afirma que seu estado de letargia e sonolência só foi realmente quebrado com a explosấo que se sucede e estremece a sala. Espantado, ele esconde-se e vê a janela 
arrebentada. Na sequência, percebe o que parece ser uma bola de fogo ardendo ao lado da televisáo:

Era amarela, puxando para o dourado. Tinha em torno de um quarto de metro entre as pontas.

Uma estrela.

Náo pude inferir como ela se precipitou céu abaixo, com a força da gravidade, e penetrou janela adentro em direçáo à TV. Mas havia uma estrela no meio da minha sala. (MOUTINHO, 2017, p. 61).

O leitor é surpreendido com a descriçăo. Assim como constatou Alazraki (2001, p. 279), desde as primeiras partes do relato, o conto neofantástico nos induz ao acontecimento insólito, sem progressâo gradual, sem preparo, sem pathos, náo há ponto culminante que gere a fantasticidade.

Do aparelho audiovisual, saiam fagulhas e um som estridente. Relutante em se aproximar daquela matéria estranha, o narrador fica confuso. Nesse momento, instaura-se um jogo entre percepçáo e discurso: "A impossibilidade da situaçáo acelerava o raciocínio e acionava imagens insólitas. Uma lagarta verde arrastando-se pelo tapete, o ovo cozido sobre a mesa de centro, uma peça de carne, com osso, dentro da travessa de vidro. Eu estava atordoado" (MOUTINHO, 2017, p. 61).

No decorrer da narrativa, percebemos que o autor elenca elementos banais como pertencentes ao insólito ante a visâo do personagem, o que contribui para uma "concepçáo do mundo como pura irrealidade" (ROAS, 2014, p. 71). Essas imagens, repentinamente, desaparecem e abrem espaço para a razâo:

Eu tinha consciência de que as estrelas têm tamanhos imensos, e a colisăo de uma delas com a Terra resultaria desde logo no fim dos tempos - ao menos para nós, humanidade. Ademais, elas morrem muito tempo antes que possamos enxergar, daqui, a sua luz. É sempre tarde demais para qualquer contato que năo visual, e distante. (MOUTINHO, 2017, p. 62, grifo nosso).

A lógica científica, entretanto, năo parece explicar aquele fenômeno. Ademais, um detalhe do discurso chama a atençâo: a informaçăo sobre a morte "precoce" das estrelas. Estes astros envolvem diversos simbolismos, principalmente ligados à fé cristă. No texto em questăo, contudo, a estrela năo se apresenta de forma claramente justificada.

Segundo Chevalier e Gheerbrant (1999, p. 404), tanto para o Antigo Testamento bíblico quanto para o Judaísmo, "as estrelas obedecem às vontades de Deus e, eventualmente, as anunciam". Seu caráter celeste faz com que elas também sejam "símbolos do espírito e, particularmente, do conflito entre as forças espirituais (ou de luz) e as forças materiais (ou das trevas)". Quanto ao seu caráter luminoso, as estrelas ainda sâo consideradas "faróis projetados na noite do inconsciente" (CHEVALIER; GHEERBRANT, 1999, p. 404).

Diante do estranhamento, o narrador vislumbra algumas especificidades daquela matéria, indicando que "devia ter no máximo trinta centímetros" e que lembraria, com seu conjunto de triângulos, "estrelas de desenho no papel" (MOUTINHO, 2017, p. 62). Além disso, sua luminosidade seria um elemento marcante. 
O personagem volta a entrar em conflito com o que vê, algo que parece ser representado pela abelha, que retorna inquieta: "Por trás de mim, ela se aproximara. Sobrevoava a estrela, como se também quisesse compreender. Zunia sem parar" (MOUTINHO, 2017, p. 62). Ele entâo relaciona a estrela a um adorno do letreiro em neon da chapelaria próxima à sua casa: "Chapelaria Estrela Distante". Nasce a dúvida quanto ao reconhecimento daquele corpo estranho como adereço que marcava o pingo do "i" do nome da loja. Observamos nessa passagem o emprego de alguns modalizadores - "talvez" e "achei" - no discurso do narrador, enfatizando a falta de clareza de seu raciocínio. Lembramos que esse foi um recurso de linguagem bastante recorrente no fantástico tradicional, importante para gerar na narrativa a incerteza diante dos acontecimentos.

Ainda com receio de tocar a estrela, ele chega mais perto e percebe que náo parece um enfeite de letreiro. Cogita pedir ajuda a alguém ou a alguma entidade das forças armadas, mas logo desiste. O mais importante naquele momento seria tirar a dúvida quanto à chapelaria, saciando o desejo de desvendar o ininteligível. O protagonista, entăo, sai de casa em direçấo à loja, tendo o cuidado de trancar a porta antes da empreitada, o que novamente sucita uma imprecisâo de comportamento.

Diante da estrela acesa incrementando o luminoso, com a tese refutada, ele reflete: "Resistia, como aquela loja de chapéus num tempo em que ninguém mais compra chapéus" (MOUTINHO, 2017, p. 63). Esse pensamento traça um interessante paralelo com a informaçăo mencionada anteriormente sobre a fugacidade da vida dos corpos celestes. A estrela do letreiro permaneceria em batalha constante com o tempo, enfrentando e se opondo ao próprio desaparecimento.

O narrador retorna visivelmente consternado: "Năo sei dizer se houve desalento ou alívio" (MOUTINHO, 2017, p. 63). Abrem-se novos caminhos de interpretaçăo. Se ele tendia a esclarecer racionalmente o acontecido, por que se demonstra também abrandecido com a quebra da motivaçăo lógica? De volta ao sobrado, ele percebe que a energia elétrica manteve-se firme, mas que a TV apagara-se por completo. A abelha desaparecera e a estrela continuava a brilhar intensamente. Esses componentes parecem apontar para a volta da calmaria e tranquilidade inicial.

No desfecho da narrativa, o personagem relata que limpou minuciosamente aquele corpo celeste com toalha umedecida em água e sabăo de coco, retirando toda a fuligem que a encobria. Revela-se o detalhe de que ela tinha cinco pontas que foram esfregadas demoradamente. A descriçăo aproxima a matéria à sua representaçăo imagética mais comum, o que reforça o caráter fantástico de sua apariçăo. Ainda consonante a Chevalier e Gheerbrant (1999):

A estrela flamejante de cinco pontas é o símbolo da manifestaçăo central da Luz, do centro místico, do foco ativo de um universo em expansăo. [...] ela representa o homem regenerado, radioso como a luz, em meio às trevas do mundo profano. [...] a estrela de cinco pontas é um símbolo do microcosmo humano [...] (CHEVALIER; GHEERBRANT, 1999, p. 404).

Evidencia-se, aqui, a questâo da intencionalidade narrativa. No fantástico tradicional, o empenho do relato é provocar o medo ou terror no leitor; o neofantástico năo produz o medo, mas situaçóes que provocam a perplexidade e, invariavelmente, portam um sentido metafórico (ALAZRAKI, 2001, p. 277). Resignado em sua condiçấo de 
portador da estrela luminosa, o narrador se regenera, assim como o ciclo da narrativa.

Por fim, o narrador menciona ter guardado a estrela "no gavetăo de meias" após ficar se perguntando "por que logo num fim de domingo, por que logo na minha sala" (MOUTINHO, 2017, p. 64). Ele năo se importa para a ausência de causalidade e acaba acondicionando o elemento imaginário no escaninho da banalidade.

\section{ALGUMAS CONSIDERAÇÕES}

Falar em leitor é compreender que existe um indivíduo para o qual o livro, enquanto objeto, e a literatura, enquanto texto transmissor de uma mensagem, destinam-se. De acordo com Zilberman (1989), uma obra literária se modifica constantemente desde o seu momento primário de criaçấo e essa metamorfose se faz necessária porque a sociedade também passa por transformaçôes. Logo, os nossos anseios literários săo modificados e novos horizontes de expectativas precisam ser alcançados.

Propor-se a desenvolver uma pesquisa que investigue o contexto histórico, social e cultural que está por trás de uma produçâo literária é sempre desafiador, além de envolver alguns riscos, como o de acabar deixando algo importante para trás. Mesmo assim, delineamos os períodos de surgimento, consolidaçăo e transformaçăo da literatura fantástica de modo a revelar que a estrutura do texto, as abordagens temáticas e a abordagem de seus personagens foram assumindo uma nova roupagem conforme as épocas pelas quais o gênero foi transitando.

Evidenciado o medo, elemento que consolidou a identidade do texto fantástico, tecemos um caminho através da revisăo dos textos teóricos de modo a revelar que esse elemento preponderante foi perdendo o seu caráter relevante e chegou à contemporaneidade assumindo uma nova perspectiva: o estranhamento, a hesitaçăo.

Marcelo Moutinho, escritor brasileiro contemporâneo, construiu uma narrativa embasada em muitos dos aspectos do neofantástico. "Caiu uma estrela em minha sala" é ambientado em um espaço urbano moderno e tem como pano de fundo a monotonia de um entediante domingo, atmosfera rompida por um acontecimento que foge às leis que regem a normalidade. Pensar que uma estrela despenca e os maiores estragos que causa sâo uma janela quebrada e uma televisâo queimada parece completamente irreal. Nâo há explicaçăo razoável do fenômeno, nem um sentido claro para sua ocorrência. 0 narrador, que inicialmente parece nâo se identificar com a falta de normas racionais de seu universo, acaba guardando o corpo celeste em sua gaveta de meias, assumindo perfeita naturalidade na convivência com o imaginário.

Aqui, o leitor náo se espanta, pois o texto neofantástico o direciona para a familiaridade com o estranho, sugerindo uma ligaçáo efetiva entre o natural e o sobrenatural. Mantendo-se sempre aberto a possíveis transformaçóes e diferentes interpretaçôes, o referido conto coerentemente náo apresenta um final redondo e fechado. No fim, tal narrativa se vale pela potencialidade de sua experiência de leitura, firmando-se como um interessante exemplo da literatura fantástica contemporânea. 


\section{REFERÊNCIAS}

ALAZRAKI, J. En busca del unicornio: Los cuentos de Julio Cortázar. Madrid: Editorial Gredos, 1983.

Que és lo neofantástico? In: ROAS, D.(org.). Teorías de lo fantástico. Madrid: Lecturas, 2001, p. 265-282.

BORDINI, M. G. O temor do além e a subversâo do real. In: ZILBERMAN, R. (org.). Os preferidos do público: Os gêneros da literatura de massa. Petrópolis: Vozes, 1987.

BOSI, A. O conto brasileiro contemporâneo. Sâo Paulo: Cultrix, 1975.

CESERANI, R. O fantástico. Traduçăo de Nilton Cezar Tridapalli. Londrina - PR: Editora da UFPR, EDUEL, 2006.

CHEVALIER, J.; GHEERBRANT, A. Dicionário de símbolos: (mitos, sonhos, costumes, gestos, formas, figuras, cores, números). 13. ed. Traduçăo de Vera da Costa Silva et al. Rio de Janeiro: José Olympio, 1999.

CORTÁZAR, J. Alguns aspectos do conto. In: Valise de cronópio. Traduçâo de Davi Arriguci Jr. e Joáo Alexandre Barbosa. Sáo Paulo: Perspectiva, 2006, p. 147-163.

Do conto breve e seus arredores. In: Valise de cronópio. Traduçăo de Davi Arriguci Jr. e Joăo Alexandre Barbosa. Sáo Paulo: Perspectiva, 2006, p. 227-237.

Do sentimento do fantástico. In: . Valise de cronópio. Traduçâo de Davi Arriguci Jr. e Joáo Alexandre Barbosa. Sáo Paulo: Perspectiva, 2006,p.175-179.

MOUTINHO, M. Caiu uma estrela na minha sala. In: Ferrugem. Rio de Janeiro: Record, 2017,p. 59-64.

TODOROV, T. Introduçâo à literatura fantástica. $3^{a}$ ed. Traduçâo de Maria Clara Correa Castello. Sáo Paulo: Perspectiva, 2004.

ROAS, D. A ameaça do fantástico: Aproximaçōes teóricas. Săo Paulo: Editora Unesp, 2014.

ZILBERMAN, R. Estética da recepçāo e história da literatura. Sâo Paulo: Ática, 1989. (Série Fundamentos).

Submetido em 20 de março de 2018

Aceito em 17 de julho de 2018 